\title{
Konkurrensfrågor i svensk straffrätt
}

\author{
Av docent NILS JAREBORG, Uppsala
}

\section{I}

1. Konkurrensfrågor uppkommer i straffrätten på en rad olika plan. Huvudfrågorna är:

(a) om en person, som teoretiskt sett kan dömas för mer än ett brott, skall dömas för mer än ett brott (brottslighetskonkurrens); och

(b) hur påföljd skall bestämmas för den som skall dömas för att ha begått mer än ett brott (påföljdskonkurrens).

2. Inom problemområdet för brottslighetskonkurrens får man anledning att skilja på två typer av frågor:

(I) skall personen anses ha begått ett eller flera brott?

(II) skall personen dömas för ett eller flera brott?

För att enkelt kunna tala om de två problemställningarna kan vi beteckna den första typen av konkurrenssituation som empirisk konkurrens $I$ och den andra som empirisk konkurrens II. Härtill kommer emellertid, att lösningen av en konkurrenssituation av den förra typen ofta är avhängig av lösningen av en helt annan art av konkurrens, nämligen konkurrens mellan straffbudens tillämpningsområden (logisk konkurrens).

Jag har gjort ett försök att kortfattat beskriva den svenska läran om brottslighetskonkurrens i kap. 11 i ,Förmögenhetsbrotten“ (Stockholm 1975). (Vad som sägs där förutsätts i fortsättningen vara känt av läsaren.) Denna beskrivning avviker i terminologi och distinktioner från det i svensk doktrin traditionella (och enligt min mening tämligen oklara) sättet att presentera konkurrensläran.

3. Vad gäller påföljdskonkurrens uppkommer konkurrensfrågor på olika sätt:

(1) hur skall påföljd bestämmas när en person samtidigt döms för mer än ett brott?

(2) hur skall påföljd bestämmas när en person redan är dömd för ett eller flera brott och skall dömas för nytt brott?

(3) hur skall man förfara när en person har ådömts flera påföljder, vilka skall verkställas samtidigt?

Frågor av typ (3) - rörande verkställighetskonkurrens skiljer sig avsevärt från övriga konkurrensfrågor, varför det finns anledning att här hålla dem utanför diskussionen. 
Fråga (2) kan synas märklig. Att den behöver ställas har att göra med att man valt en principlösning för fråga (1), som innebär att den som vid ett tillfälle döms för mer än ett brott skall ådömas en påföljd. Det framstår då inte som rimligt, att man inte tar någon hänsyn till att den som fått sin brottslighet handlagd i flera rättegångar hade kunnat åtalas för flera brott vid ett tillfälle. Rena tillfälligheter bör inte ha rättsliga konsekvenser; detsamma gäller de praktiska överväganden som ligger bakom åklagarmyndigheternas handläggning av brottsligheten i fråga. Vidare bäddar man för problem på verkställighetsstadiet, om man inte begränsar antalet påföljder för brott, som avdöms i ett flertal rättegånger inom en begränsad tidsperiod.

4. Så snart man utnyttjar andra påföljder än straff (dvs internering, ungdomsfängelse, villkorlig dom, skyddstillsyn och överlämnande till särskild vård) kommer läran om brottslighetskonkurrens i bakgrunden. Denna har en påtagligt styrande verkan, endast när rättsföljden är avsedd att ge uttryck för en rättvis reaktion på brottsligheten. Diskussionen kan därför på påföljdsstadiet för enkelhets skull begränsas till att röra frågor om straffkonkurrens, varvid även specialstraffet disciplinstraff för krigsmän kan hållas utanför.

5. Reglerna om straffkonkurrens, när någon skall vid ett tillfälle dömas för mer än ett brott är följande:

(1) Huvudregel: gemensamt straff skall utdömas för samtliga brott (BrB 1:6 st. 1; $\mathrm{BrB}=$ Brottsbalken).

(2) Undantagsregel: om särskilda skäl är därtill kan en uppdelning av påföljderna ske så att

(a) böter ådöms för viss del av brottsligheten och annan påföljd för återstoden; eller

(b) fängelse ådöms för viss del av brottsligheten och villkorlig dom eller skyddstillsyn för återstoden (BrB 1:6 st. 2).

(3) När gemensamt straff skall ådömas för flera brott bildas en ny straffskala:

(a) Böter: maximum höjs från 120 till 180 dagsböter (här bortses från andra typer av böter); finns särskilt bötesminimum för något av brotten får detta ej underskridas (BrB $25: 5)$.

(b) Fängelse: maximum höjs till sammanlagda maxima för de olika brotten, dock får inte maximum för det svåraste brottet överskridas med mer än 2 år; minimum är lika med högsta tillämpliga minimistraff; vid brott där blott böter kan följa omräknas maximum till viss tids fängelse enligt reglerna om förvandlingsstraff i § 15 lagen (1964:168) om verkställighet av bötesstraff: 120 dagsböter motsvarar fängelse i 70 dagar (BrB 26:2). 
Dessa regler skall tillämpas även i fall där någon tidigare dömts till annan påföljd än fängelse och han senare döms för nytt brott, varvid den tidigare ådömda påföljden undanröjs och han döms till fängelse som gemensamt straff för den sammanlagda brottsligheten. Se BrB 34:5-9; dessa regler berörs ej vidare.

6. När någon dömts till böter och därefter skall dömas för nytt brott, skall påföljd härför bestämmas utan hänsyn till den föregående domen.

När någon dömts till fängelse är läget annorlunda. Enligt BrB 34:1 och 3 kan domstolen välja mellan:

(A) om brottet förövats innan den tidigare domen börjat verkställas:

(1) att förordna att det tidigare ådömda straffet skall avse även det senare brottet; för detta alternativ krävs antingen att det är uppenbart, att det nya brottet i jämförelse med det eller de förra är med hänsyn till påföljden utan nämnvärd betydelse (vilket innebär att det funnits skäl till åtalseftergift enligt Rättegångsbalken 20:7 p. 2) eller att eljest synnerliga skäl är därtill.

(2) att döma särskilt till påföljd för det nya brottet; dömer man därvid till fängelse skall i möjlig mån iakttas, att maximum som skulle ha gällt enligt $\mathrm{BrB} 26: 2$ (om gemensamt straff hade ådömts) inte överskrids när fängelsestraffen läggs ihop; för att nå detta mål är det tillåtet att gå under straffminimum för det nya brottet; reservationen ,,i möjlig mån“ är föranledd av att det i mycket komplicerade situationer kan vara alltför betungande att räkna ut vilket högsta straff, som kommer i fråga.

(3) att undanröja domen på fängelse och som gemensam påföljd ådöma annan sorts påföljd, under förutsättning att den tidigare domen har vunnit laga kraft och den senare meddelas innan fängelsestraffet till fullo verkställts.

(B) om brottet förövats under verkställigheten av den tidigare domen:

(1) som under (A).

(2) som under (A), med den skillnaden att det inte finns någon särskild begränsning för det nya fängelsestraffet (innehållet i BrB 26:2 skall ej beaktas).

(3) som under (A).

Alternativ (3) är alltså aldrig tillämpligt, när fängelsestraffet är helt avtjänat innan den senare domen meddelas.

Av BrB 34:2 framgår, att om den tidigare domen är på livstids fängelse kan alternativ (2) eller (3) ej komma i fråga, så- 
vida inte det nya brottet såväl förövats som blivit föremål för dom innan verkställigheten av livstidsstraffet påbörjats.

Den viktiga gränsen går vid slutet av verkställigheten av den tidigare domen; brott förövat efter denna tidpunkt måste alltid ådömas särskild påföljd. Början av verkställigheten är bara av betydelse för storleken av nytt fängelsestraff. Tidpunkten för den förra domen är helt utan betydelse, trots att den är den väsentliga om man ville lägga vikt vid om den sammanlagda brottsligheten kunnat handläggas redan under den första rättegången. Även resonemang om (misslyckad) individuell avskräckning ger skäl för att välja denna tidpunkt som gräns. Huvudskälet för att lägga de relevanta gränserna vid senare tidpunkter torde vara de praktiska svårigheterna att verkställa ett flertal ådömda påföljder; därmed är dock inte sagt att skillnaden mellan (A) (2) och (B) (2) har fått en rimlig förklaring. Det är väl inte heller uteslutet, att man sett ett stöd för den valda lösningen i behandlingssynpunkter: först när hela straffet är avtjänat kan man bedöma om vederbörande är „,botad“ från sin brottslighet.

7. Läran om brottslighetskonkurrens innebär en i flera led förekommande utrensning av tänkbar brottslighet. Utrensningen har givetvis konsekvenser på det sättet, att det blir omöjligt att döma till straff för vissa gärningar, som eljest skulle ha kunnat bestraffas. Behovet av en sådan utrensning skall inte underskattas. Det har sitt upphov i konflikten mellan principiell åtalsplikt och praktikabilitetshänsyn; det finns helt enkelt inte resurser för att i detalj utreda och beivra ens all upptäckt brottslighet och det är inte ett vitalt samhällsintresse att lägga ner stort arbete på vad de flesta måste uppfatta som juridiska hårklyverier. Härtill kommer att det ofta är lagstiftningstekniskt praktiskt taget omöjligt att göra klart vad en kriminalisering egentligen åsyftar (även om lagstiftaren skulle vara klar över vad han vill kriminalisera och på vilket sätt det skall ske).

En sådan utrensning är befogad så länge den framstår som harmlös, dvs.

(i) när den utrensade brottsligheten är så relativt bagatellartad, att den — om den beaktades - inte skulle föranleda ytterligare straff utöver det som ändå meddelas; eller

(ii) när den utrensade brottsligheten faktiskt är beaktad genom utformningen av straffskalan för en dominerande brottstyp eller går att beakta inom ramen för den tillåtna straffmätningen $\mathrm{i}$ anledning av icke utrensad brottslighet.

Ur rättvisesynpunkt framstår utrensningen däremot som otillbörlig, om den får till konsekvens, att den som flerfaldigt överträder lagen (vid ett tillfälle eller i ett sammanhang) gynnas - 
„får rabatt" - jämfört med den som begår samma gärningar, men inte kan utnyttja konkurrensregler, eller jämfört med sammanlagda straffen när motsvarande brottslighet fördelas på flera personer (i det senare fallet får vid en rättvisebedömning dock beaktas att vad man kan kalla ,den marginella lidandegraden“ för en viss straffkvantitet varierar inom straffskalan).

Ett gynnande kan även ske på det sättet, att åtalsreglerna för ett grövre brott, som konsumerar ett lindrigare, är mer generösa än åtalsreglerna för det lindrigare brottet.

8. Även vid straffkonkurrens kan man tänka sig konsekvenser som uppfattas som att den som begått flera brott gynnas på ett otillbörligt sätt. Så är fallet, om tilllämpligt straffmaximum är begränsat på sådant sätt att det blir omöjligt att ådöma ett såsom adekvat uppfattat straff. Frågan kan uppkomma dels när gemensamt straff skall utdömas för flera brott och dels när särskilt fängelsestraff skall utdömas, men BrB 26:2 likväl skall beaktas.

9. Betraktar man konkurrensläran ur rättspolitisk synpunkt står i förgrunden den redan berörda frågan:

(1) Medför konkurrensläran oönskade konsekvenser $\mathrm{i}$ det att den som begått flera lagöverträdelser kan gynnas på ett otillbörligt sätt, antingen genom att han inte kan dömas för brott, som han borde ha dömts för, eller genom att han inte kan dömas till så högt straff som bort komma i fråga?

Vad gäller brottslighetskonkurrens finns därutöver särskild anledning att uppmärksamma tre frågekomplex (för de två första saknar det betydelse om konkurrensläran i och för sig är godtagbar) :

(2) Finns det några garantier för att konkurrensläran tillämpas någorlunda enhetligt? Finns det anledning att lagstiftningsvägen ge riktlinjer för bedömningen av konkurrenssituationer? Beaktas konkurrensfrågor i önskvärd utsträckning vid handläggningen av lagstiftningsärenden rörande kriminalisering?

(3) Måste konkurrensläran vara så invecklad och svårtillgänglig som den är (om man skall återge alla distinktioner som kan vara rättsligt relevanta)? Finns det utrymme för dels förenklingar av läran och dels ytterligare utrensning av tänkbar brottslighet, utan att ovälkomna konsekvenser följer?

(4) Finns det överhuvudtaget anledning att lägga ner energi på konkurrensfrågor? Är så litet att vinna vid arbetet på att åstadkomma en genomtänkt ordning, att det finns större anledning att låta saken vara $\mathrm{i}$ fred och inte bry sig om att systemet kanske företer påtagliga brister och att rättstilllämpningen blir ojämn? 
Personligen är jag övertygad om att det finns all anledning att ägna sig åt konkurrensfrågor, framför allt på lagstiftarplanet. Jag tror att mycket onödigt arbete, förvirring hos rättstillämpare och ojämnhet i rättstillämpning skulle försvinna, om man något mer satte sig in i konkurrensproblem och försökte skapa ett rationellt system. Den lära om brottslighetskonkurrens vi nu har är ett resultat av korttänkta lagstiftningsåtgärder. Bristerna är djupgående både systematiskt och sakligt. Åklagare och domare har sannolikt ingen som helst överblick av systemet $\mathrm{i}$ sin helhet - om man nu ens kan tala om ett system.

Bristen på rationalitet är som antytts i första hand att tillskriva försummelser på lagstiftarplanet. I sin bok ,,Straffrättens konkurrensproblem. En undersökning av förhållandet mellan straffbud." (Stockholm 1974) har Madeleine Löfmarck påvisat, att kvaliteten på det arbete, som kommit till uttryck främst i lagförarbeten, är låg och att man gärna döljer sig bakom en hänvisning till allmänna grundsatser om lösning av konkurrensproblem. Den som skall följa detta råd har utomordentliga svårigheter att hitta några allmänna grundsatser, som kan vara honom till hjälp. Det har helt enkelt inte funnits någon välutvecklad lära att konsultera.

Många av svårigheterna skulle kunna förebyggas genom eftertanke vid lagstiftning. Vid kriminalisering av ett visst förfarande borde det kunna krävas, att det blivit utrett $\mathrm{i}$ vilken mån tillämpningsområdet för det aktuella straffbudet går in på andra straffbuds områden och att man tar ställning till om ett eller flera brott skall anses begånget genom en gärning, som formellt faller under mer än ett straffbud. Sådana utredningar har varit alltför sällsynta. Bristen på intresse kan hänga samman med straffrättskommitténs lagstiftningsteknik: man koncentrerar sig på typfall av brottslighet, men drar för säkerhets skull en otydlig ring kring typfallen. Gränsen är kanske så oklar, att man inte riktigt vet när den korsar andra gränser. Eller också vet man det inte därför att man stirrar sig blind på varje särskild brottstyp och glömmer att man förutsätts ha att göra med ett rationellt system. I specialstraffrätten har man visserligen under senare år i tilltagande utsträckning börjat införa subsidiaritetsklausuler. Detta är bättre än inget. Men sker det på ett schablonartat sätt, kan man skapa större problem än man löser. Jag skall nämna ett exempel. Det är bekant, att olovlig parkering av motorfordon under vissa omständigheter kan utgöra egenmäktigt förfarande (BrB 8:8). Under 1951 års vägtrafikförordning hade man inte anledning att bekymra sig härom i det fall att gärningen kunde bestraffas som parkeringsförseelse. I nu gällande vägtrafikkungörelse (1972:603) § 113 har emellertid brott mot kungörelsen 
uttryckligen gjorts subsidiära till brott mot BrB. Konsekvensen härav är att det egentligen i varje fall av olovlig parkering först skall utredas, om gärningen innefattar egenmäktigt förfarande. I praxis har man troligen inte brytt sig om denna konsekvens. (Genom SFS 1976: 1129 har numera parkeringsförseelse avkriminaliserats med verkan från den 1 april 1977). Vi har för övrigt samma fenomen i det aktuella ärendet om avkriminalisering av fylleri (BrB 16:15). När man tagit bort fylleriparagrafen träder i stället stadgandet om förargelseväckande beteende ( $\mathrm{Br} B$ 16:16) till. Formellt sett framstår avkriminaliseringen av fylleri i stora delar som skenbar. Nu har det visserligen i propositionen (Prop. 1975/76: 113 s. 121) sagts, att fylleri enligt nutida synsätt inte bör bestraffas som förargelseväckande beteende. Men denna lagstiftning genom motiv är inte bindande för de rättstillämpande myndigheterna och kan man dömas för att direkt ur flaskan dricka mellanöl på ett torg borde man väl också kunna dömas för att på samma torg uppträda påtagligt berusad av förfriskningsmedlet. (BrB 16:15 har upphävts med verkan från den 1 januari 1977; se SFS 1976:510 och 905.)

Jag skall nämna ytterligare ett exempel, där konkurrensfrågor försummats när förslag till ny lagstiftning lagts fram. I brottmålsutredningens andra betänkande (SOU 1973:13. Snyltningsbrott och sjukförsäkringsmissbruk) föreslås särskild kriminalisering av automatmissbruk. Den föreslagna paragrafen börjar: „Begagnar någon olovligen automatapparat genom att använda falska eller främmande sedlar eller mynt...“. I betänkandet blir inte klargjort, om man med „falska sedlar och mynt" menar sådana som är „falska“ enligt terminologien i BrB kap. 14, och framförallt blir ingenting sagt om bedömningen av konkurrens med penningförfalskning eller brukande av förfalskade pengar. (I prop. 1975/76:148 har sedermera brottmålsutredningens förslag utan ändring framlagts för riksdagen. Ej heller propositionen innehåller något om konkurrensfrågor. I december 1976 har riksdagen avslagit propositionen i nu berörda del.)

När man väl har bestämt sig för att ett straffbud konkurrerar ut ett annat skall enligt nuvarande regler endast det förra komma till användning, så snart alla brottsrekvisit är uppfyllda. I dagens läge, med ökad användning av särskilda åtalsförutsättningar, finns det anledning att därutöver kräva att åtalsförutsättningarna är uppfyllda. Antag att två grannar underlåter att skotta snö på sina hustak och därmed gör sig skyldiga till brott mot allmänna ordningstadgan. En passerande person klarar sig förbi det ena huset, men när han kommer till det andra rasar snön ner och han åsamkas svår kroppsskada. Ägaren till detta hus åtalas för vållande till svår kroppsskada (BrB 3:8), men åtalet avvisas, därför att angivelse saknas. Domstolen är för- 
hindrad att döma för brott mot allmänna ordningsstadgan, eftersom brott mot BrB har företräde. Däremot finns inget hinder för att döma den som äger det hus, från vilket snön inte rasade ner. Fallet är ingen illvillig konstruktion, utan finns refererat i SvJT 1975 rf s. 63 (dock utan granne).

För det andra bör det åligga lagstiftaren att med eftertanke ta ställning till vad som skall vara brottsenhet vid kriminaliseringen av en gärningstyp. Han skall välja verb i lagtexten vilka i möjligaste mån gör klart i vilken utsträckning ett brott skall anses begånget, trots att gärningsmannens handlande går att dela upp i partier, som vart och ett formellt kan betecknas som en överträdelse av straffbudet. Praxis har här trevat sig fram till olika kriterier vid olika vanligt förekommande brott. 'T. ex. vid våldsbrott läggar man vikt vid antalet offer, vid stöld tillfällets enhet (rums- och tidsmässigt) och vid bedrägeri antalet målsägande (i kombination med vad man kan kalla antalet ärenden). Men trots dessa riktlinjer blir resultaten ibland orimliga. Antag att en lottförsäljare fyller på sin tombola med ett stort antal nitlotter och för egen räkning gör en vinst på $1000 \mathrm{kr}$. Enligt vanliga konkurrensregler måste man finna, att han begår ett bedrägeribrott mot varje lottköpare och förmögenhetsöverföringen rör sig kanske om ett fåtal ören i varje fall. I refererad praxis har man undgått denna bedömning genom att den brottslige har varit arrangör och inte försäljare, varefter man av allt att döma bestämt brottsenheten efter antalet lotterier. Av straffbud som är utomordentligt illa hopkomna ur brottsenhetssynpunkt skall särskilt de som gäller häleri (BrB 9:6) och spioneri (BrB 19:5) nämnas.

Efter önskemålet om att lagstiftare noga skall överväga de två frågor jag har berört och kommunicera resultatet av sina överväganden (helst i lagtext, men åtminstone i motiv) kommer ett önskemål om förenklingar av nuvarande system. Två av de distinktioner som nu har rättslig betydelse kan jag inte se som annat än besvärande, åtminstone systematiskt och terminologiskt.

Den ena är distinktionen mellan (1) att någon skall anses ha begått bara ett brott, trots att han överträtt mer än ett straffbud och trots att dessa straffbuds tillämpningsområden inte går in på varandra, och (2) att någon i samma situation anses ha begått mer än ett brott. Jag menar alltså att det inte finns påtagliga skäl för att säga annat än att den som överträtt flera straffbud har begått flera brott (så snart reglerna om logisk konkurrens tillåter detta). T. ex. den som förövar skadegörelse i samband med ett inbrott bör alltså anses ha gjort sig skyldig till både skadegörelse (BrB 12:1) och egenmäktigt förfarande (BrB 8:8).

Den andra distinktionen gäller skillnaden mellan idealkonkurrens och realkonkurrens. Denna är visserligen grundläggande 
i de flesta oss närstående rättssystem, utom det danska, men i det svenska systemet har den perifer betydelse. Faktum är att den medvetet avskaffades i slutet av 1930-talet. Sedan har den kommit tillbaka, men inte därför att man vill utnyttja den för att haka upp konkurrensregler. Man utnyttjar den för regler om beräkning av preskriptionstid ( $\mathrm{BrB} 35: 1$ st. 2) och om förutsättningar för allmänt åtal (Rättegångsbalken 20:4 st. 1). Därmed blir distinktionen dock en realitet även i konkurrensläran. Där medför den en onödig komplikation och jag tror inte att de nämnda stadgandena har någon viktig roll att fylla.

Med dessa önskemål tillgodosedda skulle som huvuduppgift för konkurrensläran kvarstå att ge svar på frågan hur man skall förfara vid serier av brottsliga gärningar med nära anknytning till varandra; gärningsmannen har således begått flera brott, men det kan finnas anledning att inte döma för alla. Jag skall bara nämna ett exempel. Den som på annans mark hugger ner ett träd gör sig i regel skyldig till egenmäktigt förfarande ( $\mathrm{BrB}$ 8:8). Tillgriper han därefter det löshuggna trädet med uppsått att tillägna sig det begår han stöld (BrB 8:1). Tillägnelse av trädet, t. ex. i form av försäljning, kan rubriceras som både häleri $(\mathrm{Br} B$ 9:6) och olovligt förfogande ( $\mathrm{BrB} 10: 4)$. Man kan utan svårighet utöka serien av brottsliga gärningar. Det saknas emellertid anledning - när det finns en gemensam gärningsman och ett gemensamt brottsobjekt - att döma för mer än ett brott, nämligen stöld. Frågan gäller alltså i vilken omfattning för- och efterhandlingar skall anses medbestraffade, när man döms för ett huvudbrott i en serie av brott. Troligtvis är möjligheterna små att direkt i lagtext reglera sådana situationer. Man torde t. o. m. få säga, att det närmast är en uppgift för rättsvetenskapsmän att syssla härmed. Men det skall observeras att man alltid kan arbeta utifrån en presumtion, att den som begått flera brott skall dömas för flera brott. Det gäller alltså bara att kartlägga fall, där avgörande skäl talar för att presumtionen skall genombrytas.

Enligt vad jag sagt skulle det inte vara särskilt svårt att påtagligt förenkla konkurrensläran och göra systemet relativt rationellt, begripligt och lätthanterligt. Men jag har då inte beaktat ett par verkligt besvärande saker.

Med 1942 års lagstiftning om förmögenhetsbrotten fick vi en ny kriminaliseringsteknik: åtskilliga brottstyper fördelas på normalfall och en grov och/eller ringa variant, som vardera anses vara en brottstyp för sig. Härom är kanske $\mathrm{i}$ och för sig inte så mycket mer att säga än att man - sett med legalitetsprincipens ögon - kommer ut på tunn is när man använder t. ex. „,brottet är grovt" som brottsrekvisit. Det för konkurrensläran besvärande är emellertid att man dragit in förövandet av andra brottsliga gärningar såsom särskilt beaktningsvärda omständigheter, 
vilka gör att ett normalfall i allmänhet klassificeras som grovt brott. I analogi härmed är det inte ovanligt att man i praxis upphöjer ett $\mathrm{i}$ och för sig ringa brott till ett normalfall under hänvisande till förövandet av annan brottslig gärning. I förarbetena har rekommenderats att man i sådana fall i domen nämner båda straffbuden, men bara dömer för ett brott. Det är detta jag har kallat lagkonkurrens med citering, men som enligt rådande språkbruk kallas verklig lagkonkurrens. I typiska fall av t. ex. bedrägeri förövat medelst brukande av falsk urkund, som gärningsmannen själv förfalskat, skall dömas för grovt bedrägeri medelst urkundsförfalskning. Bedrägligt beteende förövat med hjälp av osann urkund, som gärningsmannen själv undertecknat, varigenom han förövat osann försäkran, blir bedrägeri medelst osann försäkran. För åtskilliga fall av dylika konkurrenssituationer finns vägledande uttalanden i motiven. I praxis har dessa följts, åtminstone vid de vanligaste kombinationerna och särskilt vid konkurrens mellan bedrägeri och förfalskningsbrott.

Så fort situationen är litet ovanlig är det emellertid tänkt, att man inte skall döma för ett brott utan för (minst) två. Det kan t. ex. finnas anledning att inte gå upp ett steg i skalan av de tre bedrägeribrotten: då skall man döma särskilt för förfalskningen. Förfalskningen kan vara särskilt grov: då blir den knappast tillräckligt beaktad om man går upp ett steg bland bedrägerierna. Det verkar finnas en oskriven regel att man inte får hoppa två steg, dvs. från bedrägligt beteende till grovt bedrägeri, under hänvisning till att annan brottslig gärning förövats. (Situationen förvirras av att man dessutom har att ta hänsyn till konkurrens mellan förfalskningen och brukandet av det förfalskade.)

Jag tror att det är ett systematiskt och lagtekniskt misstag att på antydda oprecisa sätt klumpa ihop flera brottstyper i en. Mitt intryck är att denna teknik sällan används i andra rättssystem, även om man utnyttjar en fördelning av brott i grova, medelsvåra och ringa fall. Saken har betydelse främst vid förmögenhetsbrotten. Vid en kommande revision av dessa bör allvarligt övervägas, om man inte helt skall avstå från att använda förövandet av annan brottslig gärning som en faktor som medför att en gärning klassificeras såsom tillhörig en högre svårhetsgrad. Avstår man från denna ordning försvinner visserligen övre delen av den nu tillämpliga straffskalan, men denna utnyttjas ju inte i praktiken. Utgår man från BRÅ:s förslag till nya straffskalor (se Brottsförebyggande rådet. Rapport 1975:3. Förmögenhetsbrotten. Riktlinjer för en översyn.) blir tillämpligt maximistraff i regel detsamma om man dömer för ett grovt brott eller två medelsvåra brott. En annan konsekvens är att preskriptionstiderna förkortas. Grovt bedrägeri medelst urkundsförfalskning preskriberas efter 10 år. Dömer man i stället för bedrägeri och urkunds- 
förfalskning skulle vardera brottet preskriberas efter 5 år. Jag är inte säker på att detta är någon nackdel.

Det sagda har viss, men inte full, relevans för s.k. sammansatta brott, t. ex. rån ( $\mathrm{BrB} 8: 5$ ), våldtäkt ( $\mathrm{BrB} 6: 1$ ) och våld mot tjänsteman (BrB 17:1). Här är kriterierna klarare och konkurrensfrågor kan lättare regleras. Det går t. ex. - även i lagtext - att säga att om tvånget vid rån når en viss gräns skall dömas särskilt för detta. Oberoende härav finns det dock anledning att hålla ner antalet brottstyper. Straffrättskommitténs inriktning på att kriminalisera typfall av brottslighet — under åsidosättande av systematik och gränsdragningsfrågor — må ha motiverats av pedagogiska syften. Men frågan är om det inte har större pedagogiskt värde att i möjligaste mån begränsa antalet brottstyper och koncentrera sig på att göra dessa begripliga genom exempel och klara gränsdragningar. Ett steg i rätt riktning har tagits genom att ärekränkning av tjänstemän har upphört att vara särskilt brott. Vad gäller förmögenhetsbrotten har jag kommit till den uppfattningen att minst en fjärdedel av antalet brottstyper är obehövlig.

Ytterligare en svårighet är följande. När en domstol har att bedöma en rad brott av samma sort, är den benägen att nöja sig med att döma för t. ex. grov stöld eller grov förskingring, utan att tala om hur många brott som förövats. Detta är ganska naturligt; det viktigaste för den är att påföljden framstår som adekvat i förhållande till den sammanlagda brottsligheten. För att nå ett sådant resultat kan den emellertid tvingas till ett konstgrepp. Antag att varje brott i en serie stölder är av snatteribeskaffenhet. Men om gärningarna förövats vid ett tillfälle skulle de ha bedömts som en stöld. Jämför t. ex. 10 tillgrepp av 100 kronor med ett tillgrepp av 1000 kronor; det är väl rimligt att anse att straffet skall vara detsamma eller $i$ vart fall inte lindrigare vid de 10 tillgreppen. $\mathrm{Nu}$ är det inte ovanligt att den som gjort 10 snatterier döms för stöld och den som gjort 10 förskingringar döms för grov förskingring, osv. Motiveringen till förfarandet är ibland, men oftast inte, öppen: den omständigheten att brottet ingår $i$ en serie av likartade brott gör att det placeras i en högre svårhetsgrad. Detta innebär att alla brotten åker upp ett steg: i stället för 10 snatterier får vi 10 stölder, inte en stöld. Straffmaximum för 10 snatterier är 2 år och 6 månaders fängelse, för 10 stölder 4 års fängelse och för en stöld 2 års fängelse. Med nuvarande straffskalor för de ringa förmögenhetsbrotten gör det kanske inte så mycket att man gör på det här sättet. Men problemet blir påträngande om man, som kan förväntas, övergår till att ha enbart böter i straffskalan för ringa förmögenhetsbrott. Vad som är 10 snatterier kan då bestraffas med högst 180 dagsböter; omvandlas snatterierna till stölder blir maximum 4 års fängelse. 
Jag har svårt att tro, att man vid 1942 års lagstiftning överhuvudtaget föreställde sig möjligheten att tillhörighet till en serie av brott bör medföra att alla brotten i serien anses svårare: upprepningen är knappast en omständighet vid varje brott. Samtidigt är förfarandet ganska lätt att motivera på sätt som redan antytts: varför skall man få rabatt om man sprider ut stjälandet? Den dolda återfallsregeln fungerar inte som en vanlig återfallsregel: upprepandet av brott skall inte $\mathbf{i}$ och för sig leda till en upptrappning av straff för varje nytt brott. Man vill bara kunna göra en helhetsbedömning av brottsligheten under en viss tidsperiod och utsätta ett som man anser adekvat straff. Ett sätt att nå samma mål vore att vid likartad konkurrens utnyttja kollektivdeliktstanken, men utan att acceptera dennas processuella konsekvenser (nytt åtal för brott av samma typ begånget inom den aktuella tidsperioden skall alltså inte behöva avvisas). Man skulle således inte betrakta summan av brott som en brottsenhet, men kunna behandla den som om den vore en brottsenhet. I och för sig framstår detta som en renhårigare lösning än att laborera med svårhetsgrader. Men man skall ha klart för sig, att det fortfarande är omöjligt att göra en helhetsbedömning, om gärningsmannen sprider ut brottsligheten ytterligare, så att varje nytt snatteri begås först efter det att han dömts för det närmast föregående.

Till slut kanske man ändå finner, att varje snatteri skall behandlas som ett snatteri, osv. Det kan för övrigt bidra till att fängelsestraff, såsom är tänkt, kommer till minskad användning vid förmögenhetsbrott. Men frågan är då om inte nuvarande maximum på 120 dagsböter och framförallt maximum på 180 dagsböter som gemensamt straff på ett otillbörligt sätt kan gynna den som sprider ut sin brottslighet jämfört med den som begår brott vid ett enstaka tillfälle. Jag kan nämna att enligt de nya reglerna i Tyska förbundsrepubliken är normalt maximum 360 dagsböter och som gemensamt straff kan utdömas upp till 720 dagsböter. 